Preliminary Results of Subsurface Exploration and Monitoring at the Johnson Creek Landslide, Lincoln County, Oregon

Open-File Report 2007-1127 


\section{Preliminary Results of Subsurface Exploration and Monitoring at the Johnson Creek Landslide, Lincoln County, Oregon}

By William H. Schulz and William L. Ellis

Open-File Report 2007-1127 


\section{U.S. Department of the Interior DIRK KEMPTHORNE, Secretary}

\section{U.S. Geological Survey \\ Mark D. Myers, Director}

\section{U.S. Geological Survey, Reston, Virginia: 2007}

For product and ordering information:

World Wide Web: http://www.usgs.gov/pubprod

Telephone: 1-888-ASK-USGS

For more information on the USGS - the Federal source for science about the Earth, its natural and living resources, natural hazards, and the environment:

World Wide Web: http://www.usgs.gov

Telephone: 1-888-ASK-USGS

Any use of trade, product, or firm names is for descriptive purposes only and does not imply endorsement by the U.S. Government.

Although this report is in the public domain, permission must be secured from the individual copyright owners to reproduce any copyrighted materials contained within this report.

Suggested citation:

Schulz, W.H., and Ellis, W.L., 2007, Preliminary results of subsurface exploration and monitoring at the Johnson Creek landslide, Lincoln County, Oregon: U.S. Geological Survey Open-File Report 2007-1127, 11 p., 1 appendix. 


\section{Contents}

Abstract
Introduction.
Previously Installed Monitoring Equipment
USGS Upgrades of Monitoring Equipment
USGS Installation of Subsurface Monitoring Equipment
Vibrating-Wire Piezometers
Monitoring Data
References Cited
Appendix A. Preliminary Monitoring Data

\section{Figures}

1. Index map showing the location of the Johnson Creek landslide ....................................1

2. Map showing landslide boundaries and the locations of monitoring equipment .............2

3. Map showing the locations of monitoring equipment...................................................

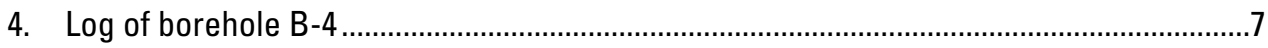

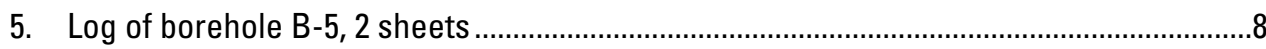

\section{Tables}

1. Depths of grouted piezometers ..................................................................................

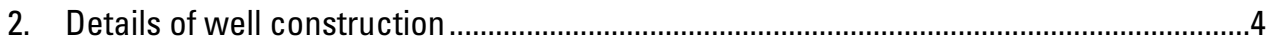

3. Estimates of landslide basal shear zone depth ............................................................

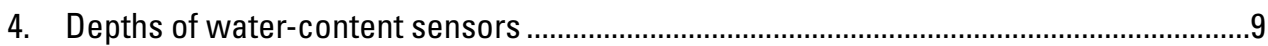




\section{Conversion Factors}

Inch/Pound to SI

\begin{tabular}{lll}
\hline \multicolumn{1}{c}{ Multiply } & \multicolumn{1}{c}{ By } & \multicolumn{1}{c}{ To obtain } \\
\hline Length & & \\
\hline inch (in.) & 2.54 & centimeter $(\mathrm{cm})$ \\
foot (ft) & 0.3048 & meter $(\mathrm{m})$ \\
mile (mi) & 1.609 & kilometer $(\mathrm{km})$ \\
\hline Pressure & & \\
\hline atmosphere, standard $(\mathrm{atm})$ & 101.3 & kilopascal $(\mathrm{kPa})$ \\
m of water at $15.5^{\circ} \mathrm{C}\left(\mathrm{m} \mathrm{H}_{2} \mathrm{O}\right)$ & 9.798 & kilopascal $(\mathrm{kPa})$ \\
inch of mercury at $60^{\circ} \mathrm{F}(\mathrm{in} \mathrm{Hg})$ & 3.377 & kilopascal $(\mathrm{kPa})$ \\
pound per square foot $\left(\mathrm{lb} / \mathrm{ft}^{2}\right)$ & 0.04788 & kilopascal $(\mathrm{kPa})$ \\
pound per square inch $\left(\mathrm{lb} / \mathrm{in}^{2}\right)$ & 6.895 & kilopascal $(\mathrm{kPa})$ \\
\hline
\end{tabular}

Temperature in degrees Celsius $\left({ }^{\circ} \mathrm{C}\right)$ may be converted to degrees Fahrenheit $\left({ }^{\circ} \mathrm{F}\right)$ as follows:

${ }^{\circ} \mathrm{F}=\left(1.8 \times^{\circ} \mathrm{C}\right)+32$

Temperature in degrees Fahrenheit $\left({ }^{\circ} \mathrm{F}\right)$ may be converted to degrees Celsius $\left({ }^{\circ} \mathrm{C}\right)$ as follows:

$$
{ }^{\circ} \mathrm{C}=\left({ }^{\circ} \mathrm{F}-32\right) / 1.8
$$

SI to Inch/Pound

\begin{tabular}{lll}
\hline \multicolumn{1}{c}{ Multiply } & \multicolumn{1}{c}{ By } & \multicolumn{1}{c}{ To obtain } \\
\hline Length & & \\
\hline centimeter $(\mathrm{cm})$ & 0.3937 & inch (in.) \\
meter $(\mathrm{m})$ & 3.281 & foot $(\mathrm{ft})$ \\
kilometer $(\mathrm{km})$ & 0.6214 & mile $(\mathrm{mi})$ \\
\hline Pressure & & \\
\hline kilopascal $(\mathrm{kPa})$ & 0.009869 & atmosphere, standard $(\mathrm{atm})$ \\
kilopascal $(\mathrm{kPa})$ & 0.10206 & m water at $15.5^{\circ} \mathrm{C}\left(\mathrm{m} \mathrm{H}_{2} \mathrm{O}\right)$ \\
kilopascal $(\mathrm{kPa})$ & 0.2961 & inch of mercury at $60^{\circ} \mathrm{F}(\mathrm{in} \mathrm{Hg})$ \\
kilopascal $(\mathrm{kPa})$ & 20.88 & pound per square foot $\left(\mathrm{lb} / \mathrm{ft}^{2}\right)$ \\
kilopascal $(\mathrm{kPa})$ & 0.1450 & pound per square inch $\left(\mathrm{lb} / \mathrm{ft}^{2}\right)$ \\
\hline
\end{tabular}

Temperature in degrees Celsius $\left({ }^{\circ} \mathrm{C}\right)$ may be converted to degrees Fahrenheit $\left({ }^{\circ} \mathrm{F}\right)$ as follows:

$$
{ }^{\circ} \mathrm{F}=\left(1.8 x^{\circ} \mathrm{C}\right)+32
$$

Temperature in degrees Fahrenheit $\left({ }^{\circ} \mathrm{F}\right)$ may be converted to degrees Celsius $\left({ }^{\circ} \mathrm{C}\right)$ as follows:

$$
{ }^{\circ} \mathrm{C}=\left({ }^{\circ} \mathrm{F}-32\right) / 1.8
$$




\title{
Preliminary Results of Subsurface Exploration and Monitoring at the Johnson Creek Landslide, Lincoln County, Oregon
}

\author{
By William H. Schulz and William L. Ellis
}

\begin{abstract}
The Johnson Creek landslide is a translational, primarily bedrock landslide located along the Oregon coast about $5 \mathrm{~km}$ north of Newport. The landslide has damaged U.S. Highway 101 many times since construction of the highway and at least two geological and geotechnical investigations of the landslide have been performed by Oregon State agencies. In cooperation with the Oregon Department of Geology and Mineral Industries and the Oregon Department of Transportation, the U.S. Geological Survey upgraded landslide monitoring systems and installed additional monitoring devices at the landslide beginning in 2004. Monitoring devices at the landslide measured landslide displacement, rainfall, air temperature, shallow soil-water content, and ground-water temperature and pressure. The devices were connected to automatic dataloggers and read at one-hour and, more recently, 15-minute intervals. Monitoring results were periodically downloaded from the dataloggers using cellular telemetry. The purposes of this report are to describe and present preliminary monitoring data from November 19, 2004, to March 31, 2007.
\end{abstract}

\section{Introduction}

The Johnson Creek landslide is located near the community of Otter Rock, Oregon, approximately $5 \mathrm{~km}$ north of Newport (fig. 1). The landslide occurs on a nearly flat marine terrace within marine terrace deposits and seawarddipping sedimentary rock (Landslide Technology, 2004), and it displaces through a coastal bluff. The landslide is as much as $26 \mathrm{~m}$ thick, $200 \mathrm{~m}$ long, and $360 \mathrm{~m}$ wide (fig. 2) and exhibits primarily translational movement. The landslide is visible on 1939 aerial photos and has affected the alignment of the Old Coastal Highway and, more recently, U.S. Highway 101 (Priest and others, 2006). Total landslide movement as estimated from a balanced geologic cross section is about 28 $\mathrm{m}$ horizontal and $6 \mathrm{~m}$ vertical (Priest and others, 2006). The largest recorded movement episode involved about $25 \mathrm{~cm}$ of horizontal displacement and several centimeters of vertical displacement and occurred January 27 - February 3, 2003. Recent movements in response to heavy rainfall have only been on the order of a few centimeters.

The Oregon Department of Transportation (ODOT) performed an investigation of the landslide during the 1970s. A more comprehensive investigation and evaluation of possible mitigation measures was initiated in late 2002 as a collaborative effort between ODOT and the Oregon Department of Geology and Mineral Industries (DOGAMI). As part of that study, six boreholes were completed along a longitudinal section of the landslide. Piezometers were installed just above the landslide basal shear zone in three of the boreholes, and inclinometer casing was installed in the other three boreholes (LT1P, LT-2P, and LT-3P are piezometer-equipped boreholes and boreholes LT-1, LT-2, and LT-3 are equipped with inclinometer casing, fig. 2). Later, manual extensometers were installed in the inclinometer boreholes when landslide movement made it

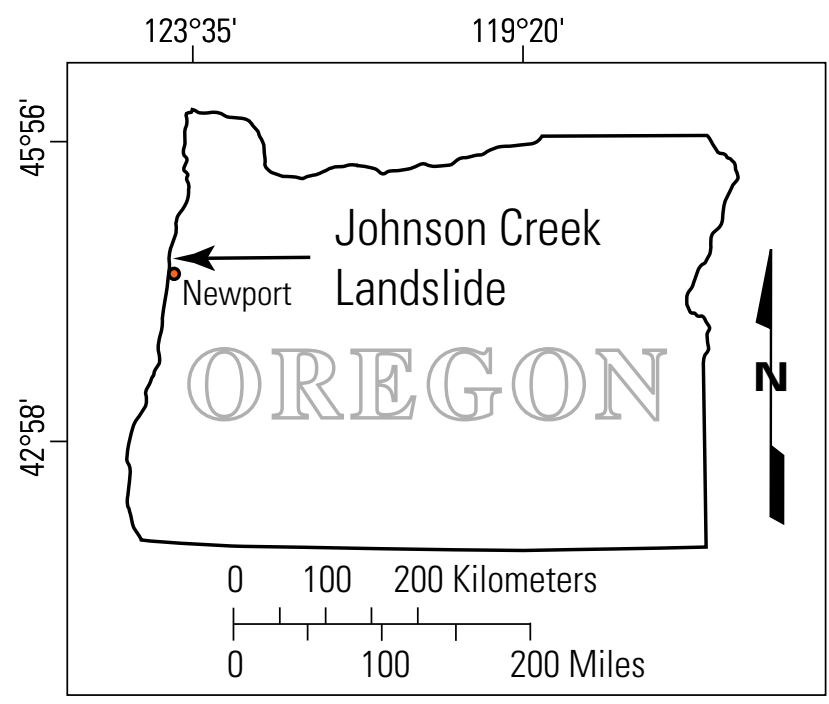

Figure 1. Index map showing the location of the Johnson Creek landslide. 


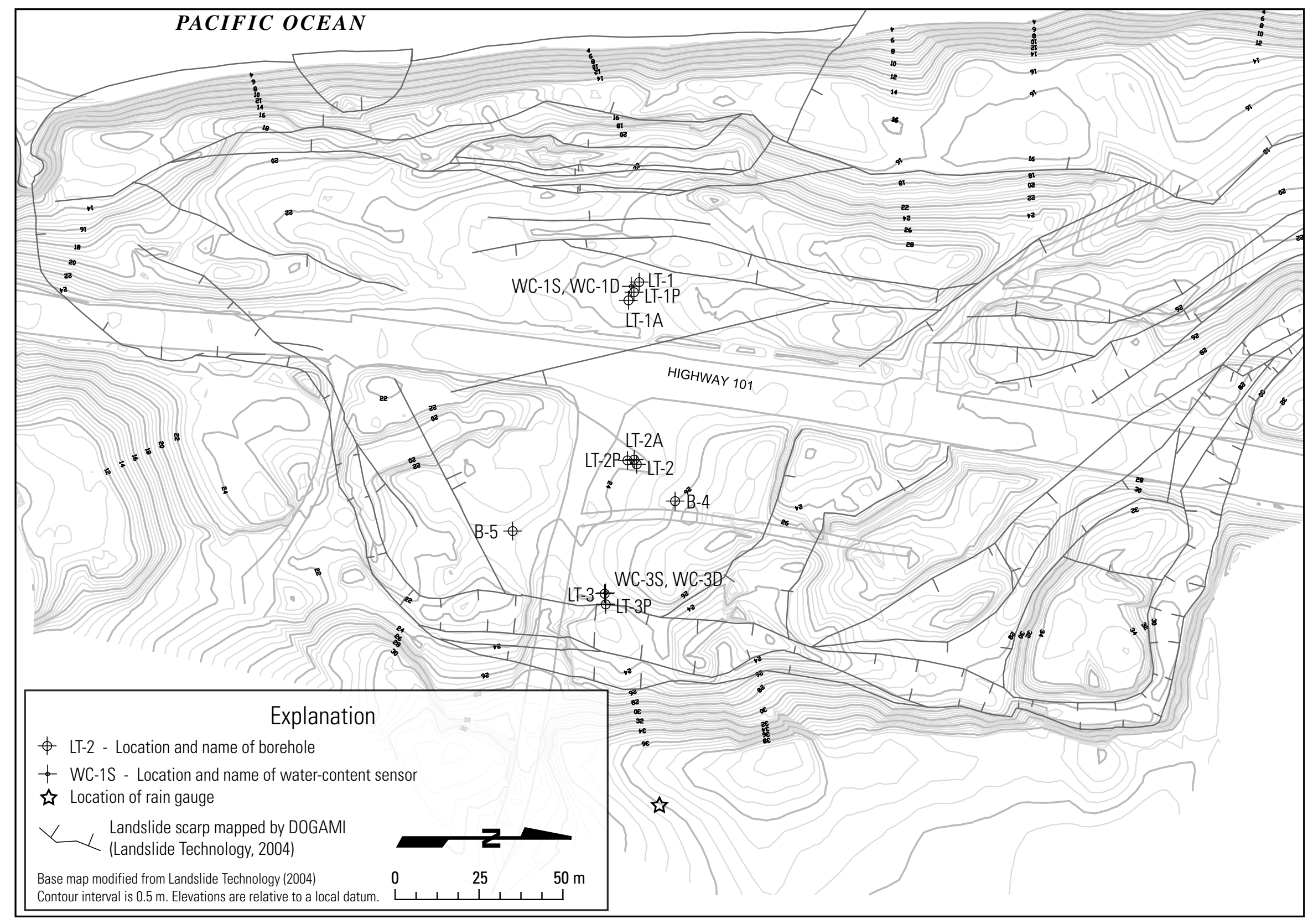


impossible to conduct inclinometer surveys through the basal shear zone. The manual extensometers consisted of wire rope that was anchored below the landslide and extended up to and past the ground surface. A rain gauge was also installed at the site. The rain gauge and piezometer outputs were recorded hourly at the site by individual dataloggers, but the extensometers were measured manually and at irregular intervals using a tape measure. A precise correlation of rainfall, ground-water pressure, and landslide movement was therefore not possible because the data were not recorded simultaneously.

During November 2004, as part of a cooperative effort with DOGAMI, the U.S. Geological Survey Landslide Hazards Program (USGS) installed new dataloggers at the site and connected electronic transducers to the extensometer cables so that all of the instruments could be read simultaneously. The dataloggers were later equipped with cell-phone telemetry so that data could be collected remotely and at regular and more frequent intervals. During November 2006, the USGS and ODOT installed fourteen additional piezometers in four new boreholes. Two vertical arrays of six piezometers each were installed in two boreholes that were backfilled with grout, and single piezometers were installed inside slotted well casing near the bottom of the other two boreholes. The vertical-array piezometers were installed to determine groundwater pressures at different levels within and just below the landslide. The single-piezometer installations were completed primarily for future hydrologic testing, but were also used to monitor groundwater levels. Shallow water-content sensors were installed in the landslide to obtain information about surface-water infiltration. This report provides preliminary monitoring data dating from the USGS installation during November 2004, brief descriptions of the monitoring equipment and data, and logs of the new boreholes completed during November 2006.

\section{Previously Installed Monitoring Equipment}

The piezometers installed as part of the 2002 investigation are vibrating-wire piezometers manufactured by Slope Indicator, Inc. The piezometers have a pressure range of 0-35 $\mathrm{m}$ of water $(0-50 \mathrm{psi})$ and a stated accuracy of \pm 0.1 percent of full scale. Each instrument also contains a thermistor or resistance temperature detector for recording temperature, and temperature corrections were made to the pressure measurements. During 2002, one piezometer was installed in each of the two boreholes LT-1P and LT-3P, and two piezometers were installed in borehole LT-2P (fig. 2). Each piezometer was installed in a 10-foot $(3.05-\mathrm{m})$ interval of the borehole that was backfilled with sand. A piezometer was installed within 2 $\mathrm{m}$ above the basal shear zone of the landslide in each borehole, and the sand backfill penetrated the shear zone. Shear-zone depths were estimated from inclinometer monitoring results as described below (Landslide Technology, 2004). In borehole LT-2P, one piezometer was placed below the landslide and the sand backfill extended from about $3 \mathrm{~m}$ to $6 \mathrm{~m}$ below the shear zone. Readings from the piezometers were made using a battery-powered datalogger located at each borehole. A tipping-bucket rain gauge was installed just east of the landslide headscarp. The rain gauge is a Global Water, Inc., model RG200, and was also connected to a battery-powered datalogger that recorded hourly rainfall amounts. Data were downloaded from the dataloggers to a laptop computer during periodic site visits (Landslide Technology, 2004).

Boreholes LT-1, LT-2, and LT-3 (fig. 2) were used to make inclinometer surveys during the early part of the 2002 investigation. These surveys suggest the depth of the basal shear zone of the landslide within the boreholes. After enough landslide movement occurred to prevent further inclinometer surveys, manual extensometers were installed in the three inclinometer casings. Each extensometer consists of 6-mm- (0.25-in.-) diameter wire rope that is anchored below the landslide in a 3-m-long concrete plug (Landslide Technology, 2004). The wire rope extends a short distance beyond the collar of the borehole, and a crimped ferrule is attached near the end of the wire rope. As the landslide moves, it overrides the wire rope below the landslide and pulls the rope from the ground surface into the borehole. Measurements of the length between the crimped ferrule and the top of the casing indicated the amount of landslide movement. These measurements were made manually using a tape measure during periodic site visits. Further details of the 2002 study and details of the instrumentation and results can be found in Landslide Technology (2004).

\section{USGS Upgrades of Monitoring Equipment}

During November 2004, the USGS initiated improvements to the instrumentation and monitoring at the Johnson Creek landslide. Automatic dataloggers powered by solarrecharged batteries were installed for monitoring the instruments at the landslide and for the first time began simultaneously recording precipitation, ground-water pressure, and landslide movement. The dataloggers are located near boreholes LT-1 and LT-3. Two dataloggers were deployed because U.S. Highway 101 passes between the locations of boreholes LT- 1 and LT-2. Sensors in borehole LT- 2 are monitored by the datalogger at borehole LT-3. The dataloggers are the CR10X model by Campbell Scientific, Inc. Data were initially retrieved from the dataloggers through periodic site visits by a DOGAMI geologist stationed in Newport, Oregon. During January 2006, cellular modems were added to the dataloggers so that the data could be retrieved remotely.

Several changes were made to the monitoring device network at the landslide. An air temperature sensor was added to the datalogger at borehole LT-3, and the rain gauge was connected to the datalogger. Cable-extension transducers were installed on the manual extensometer wire ropes so that landslide movement could be recorded electronically. Model PT8101 cable extension transducers manufactured by Cele- 
sco, Inc., were used. These devices have a range of 0 to $1.5 \mathrm{~m}$ ( 0 to 60 in) and a stated accuracy of \pm 0.25 percent of full scale. With the CR10X dataloggers, cable extension of $0.05 \mathrm{~cm}$ can be resolved. Each transducer is housed in a protective enclosure mounted on a steel pole set in concrete next to each extensometer borehole. The transducer cable extends out of the enclosure and over a pulley guide where it attaches to the wire rope that continues downhole. A spring provides tension to counterbalance the weight of the wire rope extending down the borehole.

Since November 2004, precipitation, groundwater pressures, and landslide movement have been recorded almost continuously. Site vandalism during the summer of 2005 resulted in the loss of data from the datalogger at borehole LT-3 for a period of about 11 weeks, but it was during a time of little or no precipitation, declining groundwater pressures, and no apparent landslide movement. Initially, all data were recorded hourly, but on March 9, 2006, the recording interval was reduced to 15 minutes.

\section{USGS Installation of Subsurface Monitoring Equipment}

Monitoring equipment was installed in boreholes during the weeks of November 7 and November 14, 2006, by the authors and an ODOT drilling crew led by Ed Duffy. Four boreholes for piezometers were constructed by ODOT drillers and two boreholes for soil water-content sensors were constructed by the authors as described below.

\section{Vibrating-Wire Piezometers}

Vibrating-wire piezometers (piezometers) were installed in 4.25-in.- (10.80-cm-) diameter boreholes completed using a track-mounted CME-850 rotary drill rig. Piezometers were the same make and model of those installed in 2002 (Slope Indicator, Inc., non-vented, $50 \mathrm{psi}$, vibrating-wire). Planned borehole locations were selected prior to drilling by Rex Baum and William Ellis (USGS) and George Priest (DOGAMI). Planned borehole locations were then refined in the field by George Priest and Ed Duffy. Final borehole locations were close to planned locations and are shown on figs. 2 and 3. Locations shown on figs. 2 and 3 are based on the mapped locations of existing monitoring wells (Landslide Technology, 2004; Priest and others, 2006) and measurements made using a measuring tape and a laser hypsometer. Because of the relatively large distance from known points used for mapping, the locations of boreholes B-4 and B-5 shown on figs. 2 and 3 are approximate.

Due to time constraints and previous investigation results, the boreholes were mostly blind drilled (unsampled). Boreholes LT-1A and LT-2A were drilled within a few meters of previously completed boreholes so were entirely blind drilled. The upper parts of boreholes B-4 and B-5 were blind drilled and their lower parts were sampled and logged (figs. 4 and 5). Core was retained, placed in core boxes, and provided to George Priest (DOGAMI).
Piezometers were installed in boreholes LT-1A and LT-2A, which were then backfilled with a bentonite-cement slurry using a grout pump and 0.75-in.-diameter $(1.91 \mathrm{~cm})$ tremie pipe. Ground-water monitoring wells were constructed in boreholes B-4 and B-5 and piezometers were installed in the wells. Piezometers installed in boreholes LT-1A and LT-2A were taped to the outside of the tremie pipe at depths marked on the pipe while it was lowered into the hole during installation (table 1). The piezometers were saturated and taped to the pipe in an upside-down orientation (as recommended by the manufacturer) to permit measurement of rapid pore-pressure changes. The ground-water monitoring wells consisted of Johnson Screens 1.25-in.-diameter (3.15-cm-), schedule 80 PVC pipe with 10-slot screened sections. Coaxial cable was taped to the outside of the well casing and extends to the bottom of each borehole to permit possible identification of the depth of landsliding at each well location (Kane and Beck, 1996). The annular space around each well casing was backfilled with 10/20 Colorado silica sand and Volclay coarse bentonite chips (table 2). Bentonite chips were placed in the bottom of borehole B-5 below the sand backfill and above the sand backfill in both boreholes to $0.3 \mathrm{~m}$ below ground surface. Steel, flush-mount well covers were set in concrete from $0.3 \mathrm{~m}$ below ground surface to the ground surface. One piezometer was installed into each of these wells by lowering it by its cable to the bottom of the well. These piezometers were installed right-side-up because of the small well-casing diameter and were filled with water prior to installation as recommended by the manufacturer. Both wells naturally filled with ground water to above the depths of the piezometers prior to piezometer installation. Well construction depth details are provided in table 2 .

Table 1. Depths of grouted piezometers.

[Depths are below ground surface]

\begin{tabular}{ccccccc}
\hline Borehole & \multicolumn{5}{c}{ Piezometer Depths (m) } \\
\hline LT-1A & 3.35 & 9.14 & 15.24 & 21.34 & 24.08 & 26.21 \\
LT-2A & 3.05 & 6.10 & 10.67 & 13.72 & 16.76 & 19.29 \\
\hline
\end{tabular}

Table 2. Details of well construction.

[Depths are below ground surface]

\begin{tabular}{cccc}
\hline Borehole & $\begin{array}{c}\text { Borehole } \\
\text { Depth } \\
(\mathbf{m})\end{array}$ & $\begin{array}{c}\text { Depth of } \\
\text { Well Screen } \\
(\mathbf{m})\end{array}$ & $\begin{array}{c}\text { Depth of Sand } \\
\text { Backfill (m) }\end{array}$ \\
\hline B-4 & 20.57 & $4.87-20.12$ & $4.27-20.57$ \\
B-5 & 12.04 & $1.52-10.67$ & $1.22-11.28$ \\
\hline
\end{tabular}




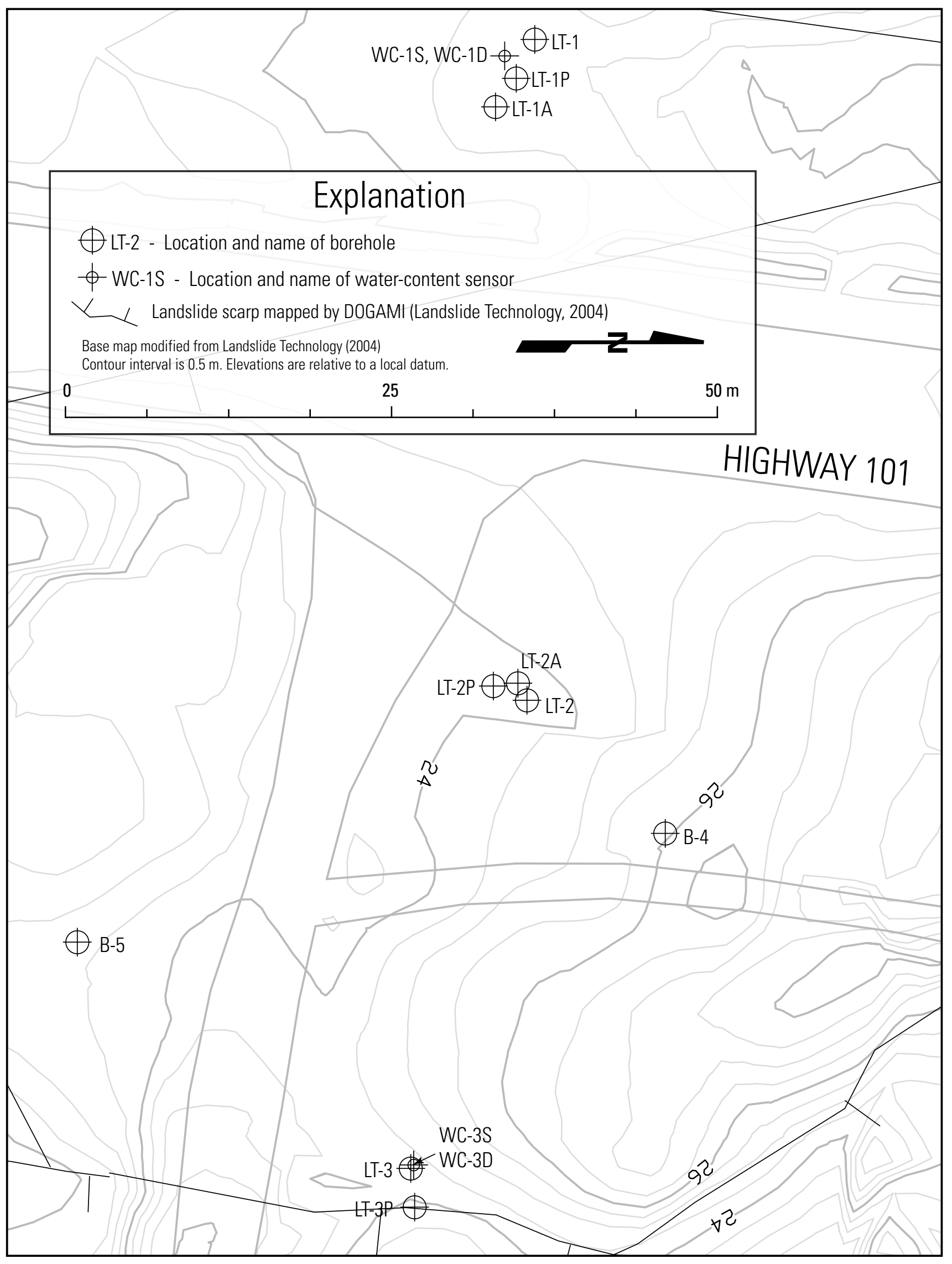

Figure 3. Map showing the locations of monitoring equipment. 


\section{U.S. GEOLOGICAL SURVEY LANDSLIDE HAZARDS PROJECT LOG OF SUBSURFACE EXPLORATION}

Project__ Johnson Creek landslide

Borehole Name

B-4

Location_North of forest road, east of HWY 101, about $5 \mathrm{~km} \mathrm{~N}$ of Newport

Date_November 14-15, 2006

Exploration Equipment_Track-mounted CME 850, 2 5/8 in. dia. core Geologist_Bill Schulz

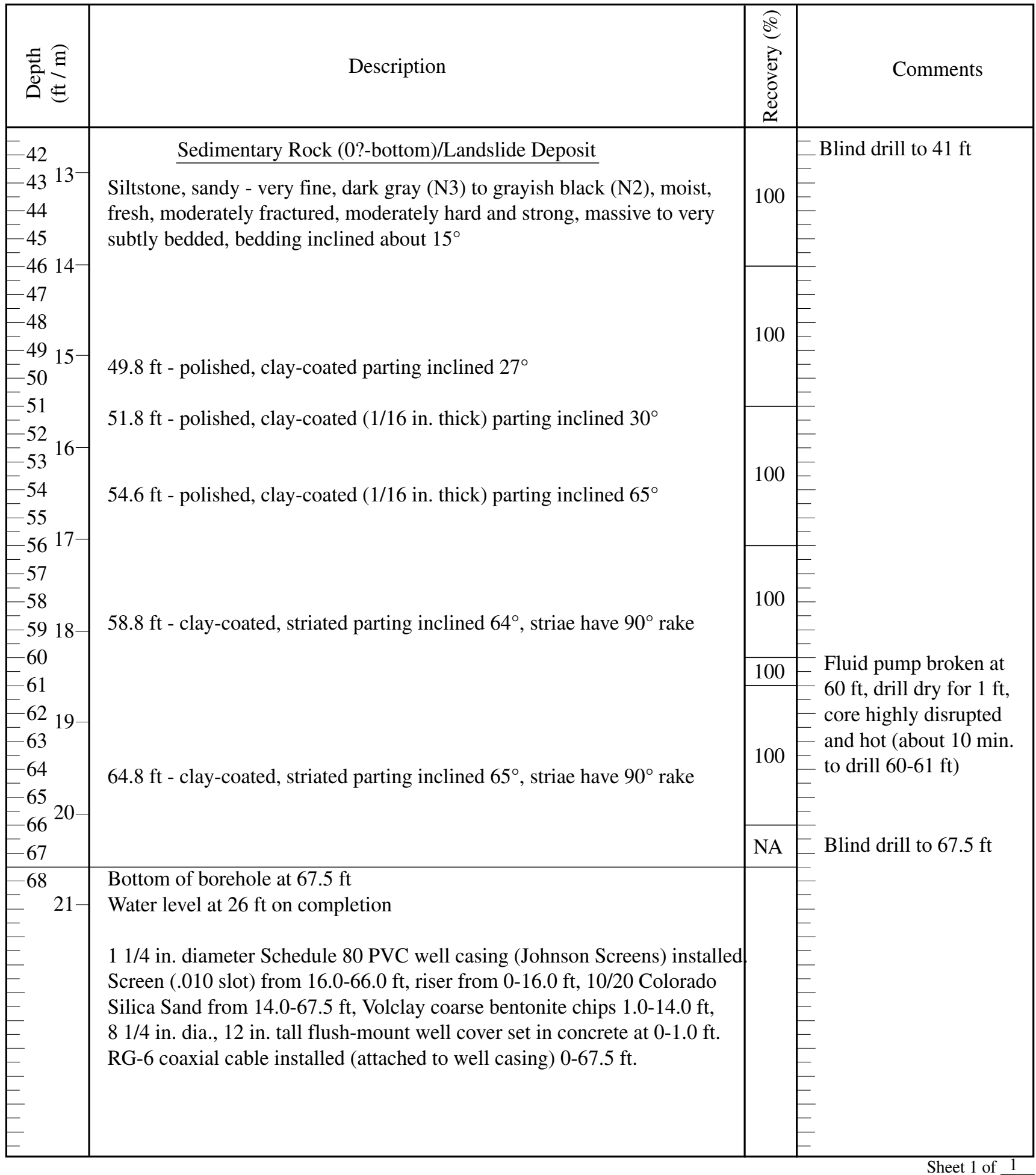

Figure 4. Log of borehole B-4. 


\section{U.S. GEOLOGICAL SURVEY LANDSLIDE HAZARDS PROJECT LOG OF SUBSURFACE EXPLORATION}

Project__Johnson Creek landslide

Borehole Name

B-5

Location_South of forest road, east of HWY 101, about $5 \mathrm{~km} \mathrm{~N}$ of Newport

Date_November 14, 2006

Exploration Equipment Track-mounted CME 850,2 5/8 in. dia. core Geologist_Bill Schulz

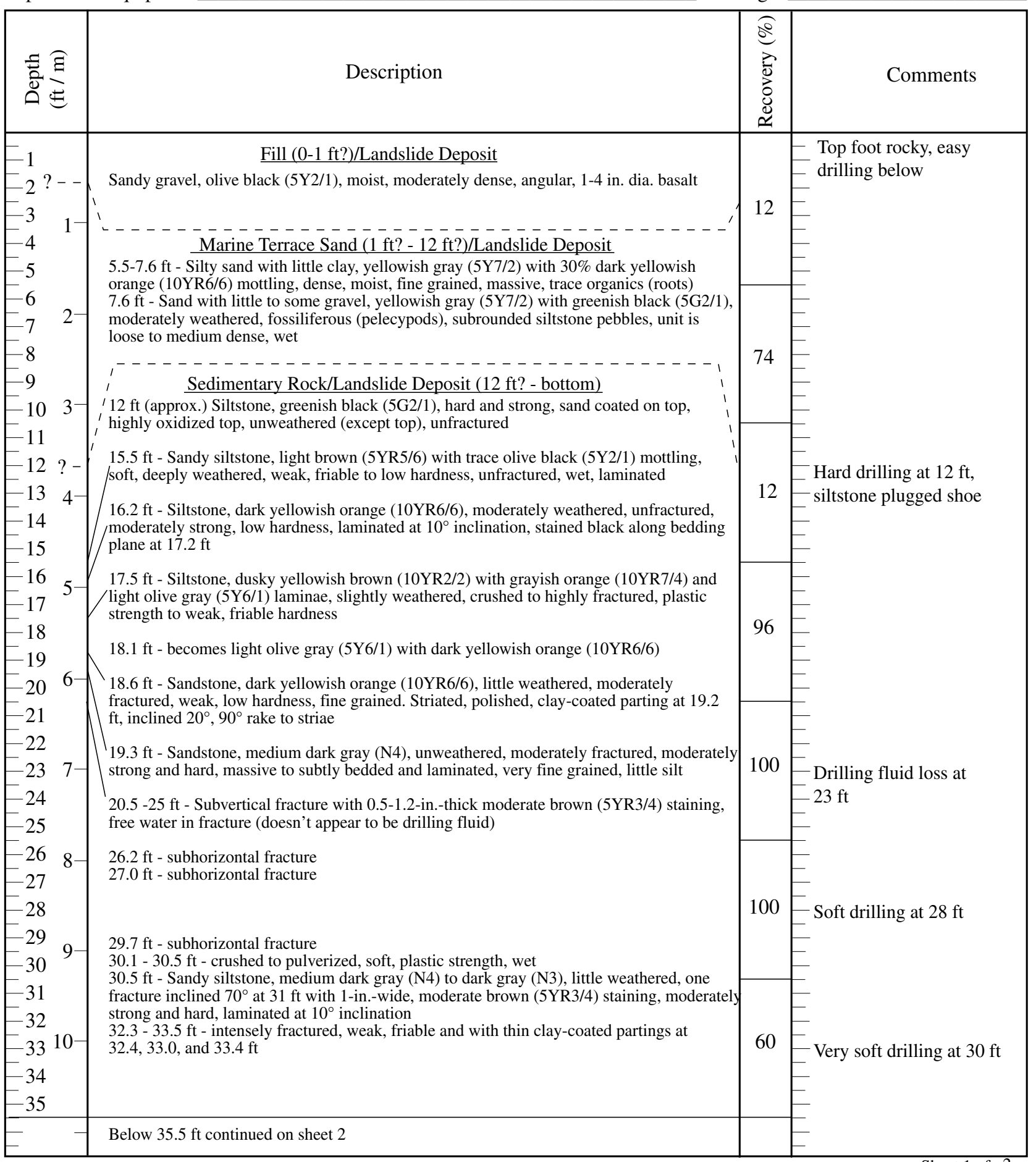

Figure 5. Log of borehole B-5. 
Project_Johnson Creek landslide Date November 14, 2006 Borehole Name_B-5

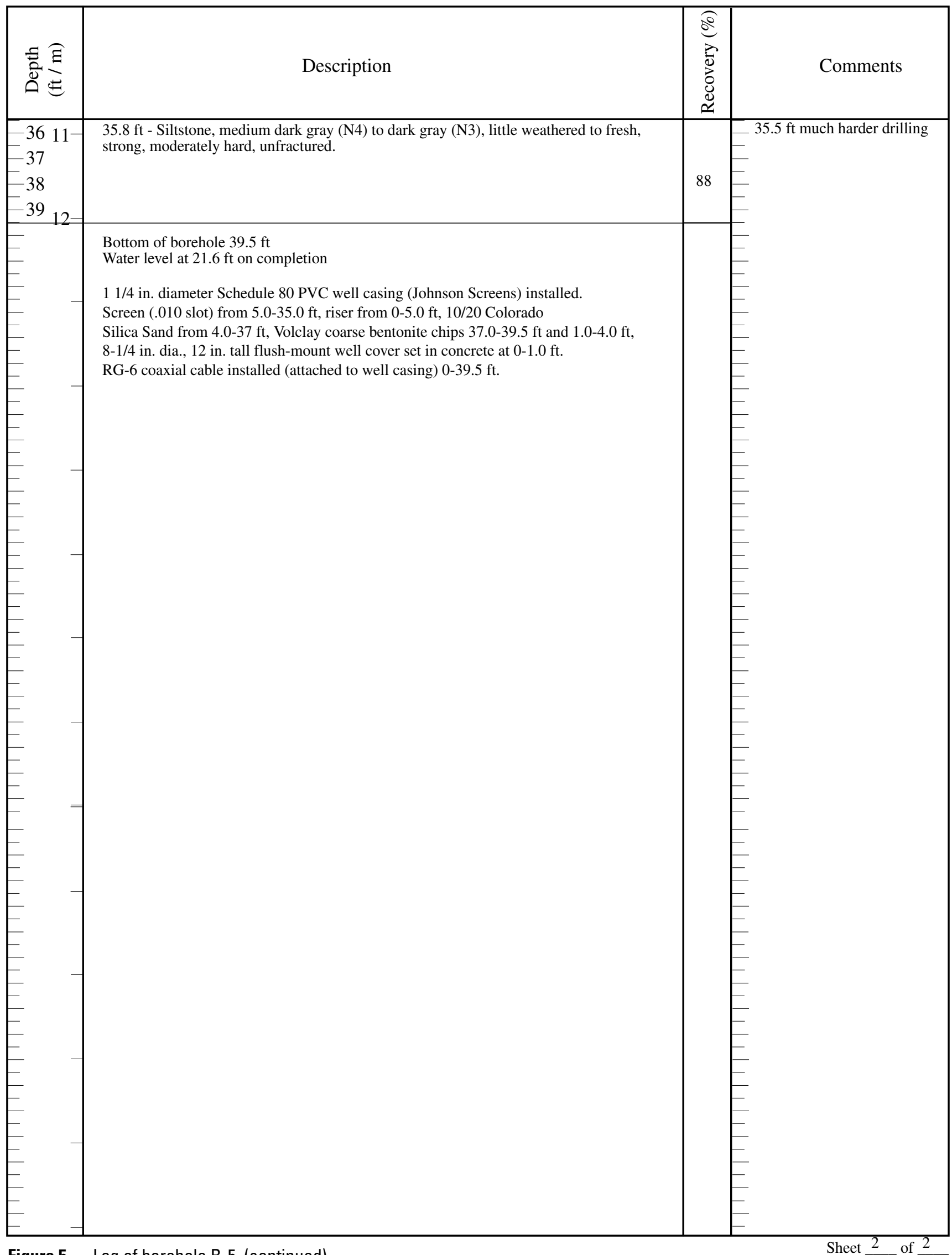

Figure 5. Log of borehole B-5. (continued) 
Depths of piezometers in the grouted boreholes (LT-1A and LT-2A) were selected based on depths of terrace sand and landsliding identified from previous subsurface exploration and monitoring results (Landslide Technology, 2004). Plots of borehole LT-1 and LT-2 inclinometer measurements (Landslide Technology, 2004) show that all shear displacement of the inclinometer casings occurred within a 1.2-m-thick zone, indicating that the landslide basal shear zone at these locations is less than $1.2 \mathrm{~m}$ thick. About 64 percent and 83 percent of the shear displacement of the inclinometer casing at boreholes LT-1 and LT-2, respectively, occurred within a zone $0.6 \mathrm{~m}$ thick, strongly suggesting that the basal shear zone at these locations is less than $0.6 \mathrm{~m}$ thick and probably less than $0.3 \mathrm{~m}$ thick. These suggestions are based on the senior author's observations of inclinometer monitoring results followed by direct observations of the shear zones adjacent to the inclinometers in numerous other landslides. Our interpretation of landslide depth at boreholes LT-1 and LT-2 is given in table 3. Probable depths are based on the assumption that the shear zone is a plane centered within the interval displaying shear displacement of the inclinometer casing. We selected depths for piezometers installed in boreholes LT-1A and LT-2A using depths shown in table 3 , a cross section of the landslide (modified from fig. 18, Landslide Technology, 2004), locations of boreholes LT-1A and LT-2A (figs. 2 and 3), and relative ground-surface elevations between all boreholes.

Table 3. Estimates of landslide basal shear zone depth.

[Depths are below ground surface]

\begin{tabular}{cccc}
\hline Borehole & $\begin{array}{c}\text { Maximum } \\
\text { Depth }(\mathbf{m})\end{array}$ & $\begin{array}{c}\text { Minimum } \\
\text { Depth }(\mathbf{m})\end{array}$ & $\begin{array}{c}\text { Probable } \\
\text { Depth }(\mathbf{m})\end{array}$ \\
\hline LT-1 & 26.52 & 25.30 & 25.81 \\
LT-1A & 25.76 & 24.54 & 25.05 \\
LT-2 & 18.59 & 17.37 & 17.77 \\
LT-2A & 18.62 & 17.34 & 17.74 \\
LT-3 & 6.46 & 5.79 & 6.13 \\
\hline
\end{tabular}

Piezometers installed in borehole LT-1A were connected to the datalogger previously installed at that location. An additional piezometer was connected to this datalogger and left exposed to the atmosphere to measure atmospheric pressure. Piezometers installed in boreholes LT-2A, B-4, and B-5 were connected to the datalogger previously installed near borehole LT-3.

\section{Water-Content Sensors}

Water-content sensors were installed into undisturbed soil at the bottom of boreholes made using hand-operated soilsampling equipment manufactured by Geoprobe. The sensors are Decagon Devices, Inc., $\mathrm{ECH}_{2} \mathrm{O}$ model EC-5 dielectric sensors. The sensors produce an output voltage that depends on the dielectric constant of the medium surrounding the sensors. The EC-5 has a claimed resolution of $0.001 \mathrm{~m}^{3} / \mathrm{m}^{3}$ and accuracy of at least $0.003 \mathrm{~m}^{3} / \mathrm{m}^{3}$ in all soils with salinity below 8 decisiemens per meter.

Boreholes for the water-content sensors were made by driving a 0.6-m-long, 5.1-cm-diameter, cylindrical steel sampler using a 22-kg electric breaker hammer powered by a generator. Locations of the sensors are shown on figs. 2 and 3. Both locations had organic rich sand and silt to about one meter below ground surface and silty sand and sandy silt below that. Sensor depths are given in table 4. WC-1 sensors were connected to the datalogger located near borehole LT-1, and WC-3 sensors were connected to the datalogger located near borehole LT-3. Sensor WC-1D does not appear to be fully functional; it appears to measure very subtle changes in water content at times when large changes are measured by the other sensors, but it does not appear to provide accurate absolute measurements or detect moderate and small changes in water content.

Table 4. Depths of water-content sensors.

[Depths are below ground surface]

\begin{tabular}{cc}
\hline Sensor & Depth (m) \\
\hline WC-1S & 1.50 \\
WC-1D & 2.40 \\
WC-3S & 1.60 \\
WC-3D & 3.10 \\
\hline
\end{tabular}

\section{Monitoring Data}

Appendix A is a Microsoft Excel ${ }^{\mathrm{TM}}$ workbook file containing monitoring data from the Johnson Creek landslide from the beginning of USGS monitoring in November 2004 through March 2007. The workbook contains four worksheets. Because two dataloggers were used, the data are grouped into two sets according to datalogger location. The data are further divided into two groups according to monitoring time periods; one period covers November 19, 2004 to December 12, 2006, and the other period covers December 12, 2006 to March 30,2007 . The latter dataset includes data from the additional piezometers and shallow water-content sensors installed at the site in late 2006.

Worksheet 1 (Appendix A) provides data from sensors in and near the LT- 1 boreholes and worksheet 2 provides data from sensors in and near the LT-2, LT-3, B-4, and B-5 boreholes for November 19, 2004 - December 12, 2006. In addition to date and time information, the data include piezometer temperature ("piez temp") in degrees Centigrade, piezometer ("VWP") frequency ("freq") in kilohertz, pressure head 
("m of water") at each piezometer, the extensometer reading ("disp") in centimeters, and battery voltage ("battery"). In addition, the data in worksheet 2 include air temperature ("degrees C") and rainfall ("precip") in millimeters for the recording interval. Pressure head values in meters of water were calculated according to instrument calibration records and manufacturer specifications, and include temperature corrections.

Worksheet 3 (Appendix A) provides data from sensors in and near the LT-1 boreholes and worksheet 4 provides data from sensors in and near the LT-2, LT-3, B-4, and B-5 boreholes for December 12, 2006 - March 31, 2007. These worksheets include a continuation of the data contained in worksheets 1 and 2, and also the data from the water-content sensors and additional piezometers that were installed during November 2006. The new data include volumetric soil water content in volumetric fraction (percent water/100), the frequency ("kHz") and temperature ("deg. C") of each piezometer ("VWP") at the specified depth (in meters), and the calculated pressure head ("m of water") at each piezometer. Data from the piezometer intended to measure atmospheric pressure is labeled "barometer" in worksheet 3.

Blank cells in any of the worksheets represent missing data, or values that must be calculated using missing data. Occasionally there are time gaps or offsets that result from periods when the dataloggers were off, or when clock adjustments were made.

\section{References Cited}

Kane, W.F., and Beck, T.J., 1996, Rapid slope monitoring: Civil Engineering, v. 66, no. 6, p. 56-58.

Landslide Technology, 2004, Geotechnical investigation, Johnson Creek landslide, Lincoln County, Oregon: Oregon Department of Geology and Mineral Industries, Open-File Report OFR O-04-05, 115 p.

Priest, G.R., Allan, Jonathan, Niem, Alan, Christie, S.R., and Dickenson, S.E., 2006, Interim report: Johnson Creek landslide project, Lincoln County, Oregon: Oregon Department of Geology and Mineral Industries, Open-File Report OFR O-06-02, 85 p. 


\section{Appendix A. Preliminary Monitoring Data}

